\title{
COMMENTARY
}

\section{Atrial fibrillation is not just an artefact in the ICU}

\author{
Philippe Seguin* and Yoann Launey \\ See related research by Meierhenrich et al., http://ccforum.com/content/14/3/R108
}

\begin{abstract}
Atrial fibrillation (AF) is common in the intensive care unit (ICU) and is particularly frequent (46\%) in septic shock patients. Inflammation favours AF in the general population, and there is a growing body of evidence that inflammation also plays a role in AF occurring after cardiac surgery but also in the general ICU. How such a finding could modify the therapeutic approach remains elusive. The impact of AF on mortality is not clearly demonstrated in the ICU, with AF reflecting essentially the severity of the underlying disease.
\end{abstract}

Atrial fibrillation (AF) onset in the intensive care unit (ICU) is attracting widespread attention because of its frequency and prognostic significance. In the previous issue of Critical Care, Meierhenrich and colleagues complete the description of new-onset AF in the ICU in a selected population of patients suffering from septic shock [1]. They found that $46 \%$ of their patients developed AF and this arrhythmia was significantly associated with increased ICU length of stay without affecting mortality. Interestingly, they reported a significant and continuous increase in C-reactive protein levels the days before the occurrence of $\mathrm{AF}$, corroborating previous findings on the hypothesis of an inflammatory substrate in AF onset [2].

AF is the most significant arrhythmia in the ICU. The risk to develop AF in the ICU is largely superior to that of the general population but differs with regard to the type of ICU involved. Indeed, the risk is estimated to be $4 \%$ in the general population, from 4 to $9 \%$ in the general ICU and an incidence of $32 \%$ has been recently reported in a cardiac surgical ICU [3-9].

How could we explain such a difference? In fact, AF is considered both a cardiac disease and a noncardiac disease. Age, essential hypertension, ischaemic heart

*Correspondence: philippe.seguin@chu-rennes.fr

Service d'Anesthésie-Réanimation 1, Service de Réanimation Chirurgicale, Hôpital Pontchailllou, 2 rue Henri Le Guilloux, 35033 Rennes cedex, France failure and valvular heart disease are well recognized as cardiac components of AF, and on the contrary inflammation, whatever its origin, is now considered an important noncardiac trigger [4]. In this context, it is not surprising that cardiac surgery generates a higher incidence of AF, and several data support this assumption. Effectively, in cardiac surgery the risk of AF is common in the first 3 postoperative days and a strength correlation has been found between various inflammatory parameters and postoperative arrhythmia $[7,10]$. In a prospective double-blind study, 236 patients undergoing elective heart surgery were randomized to receive placebo or dexamethasone after the induction of anaesthesia. Patients who received dexamethasone had significantly less new-onset AF in the 3 postoperative days (18.9\% vs. $32.3 \%, P=0.027$ ) [11]. In a recent prospective, multicentre, double-blind study performed in cardiac surgery, hydrocortisone administered the day before and during the next 3 postoperative days significantly reduced the occurrence of AF ( $30 \%$ vs. $48 \%, P=0.004$ ) [12]. In the same way, it has been showed that nonsteroidal anti-inflammatory drugs administered in the postoperative course protected patients from AF [7]. Finally, in general ICU patients and in trauma patients requiring admission to the ICU, the presence of a systemic inflammatory response syndrome was found to be linked to the risk to develop AF $[5,13]$.

We probably better understand why Meierhenrich and colleagues found a $46 \%$ incidence of $\mathrm{AF}$ in septic shock patients [1]. Septic shock is a severe systemic inflammatory disease, and the regular and significant increase in C-reactive protein before onset of AF is another factor highlighting the role of inflammation in the genesis of AF in the ICU. Nevertheless, we have to keep in mind that inflammation alone is probably insufficient to generate such a high AF incidence, and other contributing factors should not be underestimated such as catecholamine use, central venous catheter catheterization and/or fluid shifts $[3,6,9,14]$. Finally, it would be interesting to know whether, in the study by Meierhenrich and colleagues, patients received anti-inflammatory drugs, notably steroids and/or activated protein $\mathrm{C}$, and whether those patients who did receive such therapy experienced less AF.

What is the impact of AF on mortality in ICU patients? This is an old debate, and Brathwaite and Weissmann 
already clearly discussed this dilemma in 1998 [3]. Most studies concerning AF in the ICU found that this arrhythmia increases ICU and hospital lengths of stay and/or mortality, but these patients were also the most severely ill $[3,5,6,8,9]$. In a prospective observational study conducted in trauma patients, AF was observed in the most severe patients and carried a higher mortality [13]. Nevertheless, the standardized mortality ratio was similar in patients who had AF and in patients who did not have $\mathrm{AF}$, suggesting $\mathrm{AF}$ is rather a marker of severity without major impact on mortality [13]. Moreover, in a larger multicentre study performed in 26 European general ICUs, Annane and colleagues showed that, after adjustment and propensity score use, supraventricular arrhythmia did not increase the risk of hospital death [15]. Interestingly, in the study by Meierhenrich and colleagues the mortality in septic shock patients was not influenced by the presence of AF despite a higher Sequential Organ Failure Assessment score in AF patients [1].

$\mathrm{AF}$ is not just an artefact in the ICU, and the article of Meierhenrich and colleagues contributes to our better understanding of the mechanisms contributing to AF in the ICU. Nevertheless, the impact of such findings remains elusive from a therapeutic point of view.

Abbreviations

$A F$, atrial fibrillation; ICU, intensive care unit.

\section{Competing interests}

The authors declare that they have no competing interests.

Published: 22 July 2010

\section{References}

1. Meierhenrich R, Steinhilber E, Eggermann C, Weiss M, Voglic S, Bögelein D, Gauss A, Georgieff M, Stahl W: Incidence and prognostic impact of newonset atrial fibrillation in patients with septic shock: a prospective observational study. Crit Care 2010, 14:R108.

2. Issac TT, Dokainish H, Lakkis NM: Role of inflammation in initiation and perpetuation of atrial fibrillation: a systematic review of the published data. J Am Coll Cardiol 2007, 50:2021-2028.

3. Brathwaite $D$, Weissman C: The new onset of atrial arrhythmias following major noncardiothoracic surgery is associated with increased mortality. Chest 1998, 114:462-468.
4. FFuster V, Rydén LE, Cannom DS, Crijns HJ, Curtis AB, Ellenbogen KA, Halperin JL, Le Heuzey JY, Kay GN, Lowe JE, Olsson SB, Prystowsky EN, Tamargo JL, Wann S, Priori SG, Blanc JJ, Budaj A, Camm AJ, Dean V, Deckers JW, Despres C, Dickstein K, Lekakis J, McGregor K, Metra M, Morais J, Osterspey A, Zamorano $J L$, Smith SC Jr, Jacobs AK, Adams CD, Anderson JL, Antman EM, Hunt SA, Nishimura R, Ornato JP, Page RL, Riegel B: ACC/AHA/ESC 2006 guidelines for the management of patients with atrial fibrillation - executive summary: a report of the American College of Cardiology/American Heart Association Task Force on Practice Guidelines and the European Society of Cardiology Committee for Practice Guidelines (Writing Committee to Revise the 2001 Guidelines for the Management of Patients With Atrial Fibrillation). J Am Coll Cardiol 2006, 48:854-906.

5. Knotzer H, Mayr A, Ulmer H, Lederer W, Schobersberger W, Mutz N, Hasibeder W: Tachyarrhythmias in a surgical intensive care unit: a case-controlled epidemiologic study. Intensive Care Med 2000, 26:908-914.

6. Seguin $P$, Signouret $T$, Laviolle B, Branger B, Malledant Y: Incidence and risk factors of atrial fibrillation in a surgical intensive care unit. Crit Care Med 2004, 32:722-726.

7. Mathew JP, Fontes ML, Tudor IC, Ramsay J, Duke P, Mazer CD, Barash PG, Hsu $\mathrm{PH}$, Mangano DT: A multicenter risk index for atrial fibrillation after cardiac surgery. JAMA 2004, 291:1720-1729.

8. Artucio H, Pereira M: Cardiac arrhythmias in critically ill patients: epidemiologic study. Crit Care Med 1990, 18:1383-1388.

9. Bender JS: Supraventricular tachyarrhythmias in the surgical intensive care unit: an under-recognized event. Am Surg 1996, 62:73-75.

10. Bruins $P$, te Velthuis $H$, Yazdanbakhsh AP, Jansen $P G$, van Hardevelt FW, de Beaumont EM, Wildevuur CR, Ejjsman L, Trouwborst A, Hack CE: Activation of the complement system during and after cardiopulmonary bypass surgery: postsurgery activation involves $C$-reactive protein and is associated with postoperative arrhythmia. Circulation 1997, 96:3542-3548.

11. Yared JP, Starr NJ, Torres FK, Bashour CA, Bourdakos G, Piedmonte M, Michener JA, Davis JA, Rosenberger TE: Effects of single dose, postinduction dexamethasone on recovery after cardiac surgery. Ann Thorac Surg 2000, 69:1420-1424.

12. Halonen J, Halonen P, Jarvinen O, Taskinen P, Auvinen T, Tarkka M, Hippelainen M, Juvonen T, Hartikainen J, Hakala T: Corticosteroids for the prevention of atrial fibrillation after cardiac surgery: a randomized controlled trial. JAMA 2007, 297:1562-1567.

13. Seguin $P$, Laviolle $B$, Maurice $A$, Leclercq $C$, Malledant $Y$ : Atrial fibrillation in trauma patients requiring intensive care. Intensive Care Med 2006, 32:398-404.

14. Trohman RG: Atrial fibrillation in the critically ill: common sense for a common problem. Crit Care Med 2008, 36:1681-1682.

15. Annane D, Sebille V, Duboc D, Le Heuzey JY, Sadoul N, Bouvier E, Bellissant E: Incidence and prognosis of sustained arrhythmias in critically ill patients. Am J Respir Crit Care Med 2008, 178:20-25.

doi:10.1186/cc9093

Cite this article as: Seguin $P$, Launey $Y$ : Atrial fibrillation is not just an artefact in the ICU. Critical Care 2010, 14:182. 